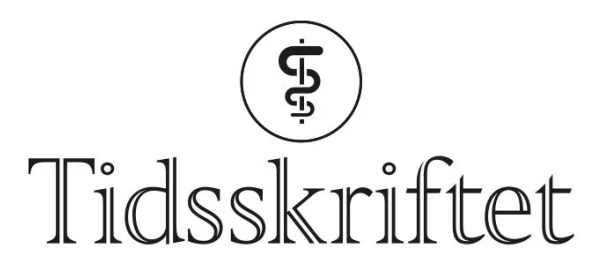

DEN NORSKE LEGEFORENING

\title{
Hvem tar jobben?
}

LEGELIVET

CECILIE NORMANN BIRKELI

cecilie.normann.birkeli@lefo.no

Legeforskningsinstituttet (LEFO)

\section{Det har lenge vært oppmerksomhet rundt manglende rekruttering til allmennmedisin i Norge. Forskning på årsaker - hvorfor leger velger seg bort eller slutter i allmennmedisin - kan gi kunnskap om forhold som påvirker dette valget.}

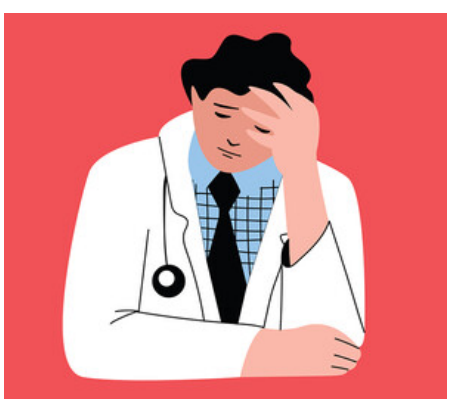

Illustrasjon: Natalya

Perevoshchikova/iStock

En studie publisert våren 2020 pekte på flere viktige årsaker til at leger valgte seg bort fra allmennmedisin (1). Av 1153 leger i Legeforskningsinstituttets legepanel som ikke var allmennleger/fastleger, hadde 39,9\% vurdert allmennmedisin, men likevel ikke valgt det, og $16 \%$ hadde jobbet som fastlege/allmennlege, men sluttet. Disse legene ble spurt om hvorfor de hadde valgt seg bort fra allmennmedisin. Administrativ byrde, lite faglig nettverk og miljø, lite samarbeid med andre kolleger og kostbart å etablere egen praksis ble angitt som de viktigste årsakene. Men også flere andre årsaker spilte inn, og dette indikerer at bildet er sammensatt. Hvordan kan denne kunnskapen omsettes til en praktisk forbedring av fastlegeordningen, for faget og for befolkningen?

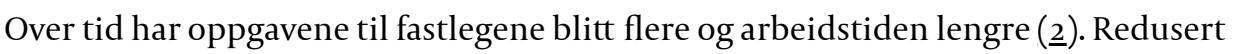
liggetid i sykehus har gitt fastlegene større ansvar for pakkeforløp og oppfølging av sykdomsforløp. Økte pasientforventninger og tilgang til kunnskap om medisinske problemstillinger tilknyttet pasientens helse stiller økte krav til utvidet kunnskap hos 
fastleger. Samtidig har pandemien gjort sitt inntog og medført et ekstra ansvar for smittevern, smitteoppsporing og vaksinering av pasientene de har ansvar for, som synliggjør ytterligere noen av de mange rollene de skal fylle i sin arbeidshverdag.

\section{«Å styrke faget ved å gi rom for faglig oppdatering og knytte faglige nettverk er ikke nødvendigvis bare et spørsmål om penger, men også tilrettelegging og bedre rammevilkår»}

Diskusjonen om hvorfor det er vanskelig å rekruttere og beholde fastleger kan i stor grad ha dreid seg om enkeltårsaker. Flere forhold bør derfor vurderes hvis man ønsker å få flere unge til å velge allmennmedisin og $ø$ nsker å beholde leger i faget. Blant legene som hadde vurdert, men likevel valgt bort allmennmedisin, var det mange som oppga at dette valget var tilfeldig. Dette kan peke på at spesialitetsvalg styres mer av hvilke muligheter man faktisk får underveis i utdanningsløpet og når og hvor man får disse mulighetene. En inngang til praksis som baserer seg på reelle valg og ikke tilfeldigheter kan bidra til å styrke både rekruttering og motivasjon for faget. Både evaluering av prosjekter med faste stillinger og strukturert veiledning for leger i spesialisering er viktig å gjennomføre og ta konsekvensene av. Samtidig peker studien på betydningen av bedre faglige nettverk og faglig oppdatering for å velge å bli i faget. Å styrke faget ved å gi rom for faglig oppdatering og knytte faglige nettverk er ikke nødvendigvis bare et spørsmål om penger, men også tilrettelegging og bedre rammevilkår, for eksempel reduksjon av arbeidsbelastning og arbeidstid.

Erfaringene fra denne pandemien har også synliggjort andre måter å jobbe sammen på gjennom digitale løsninger, som igjen kan gjøre terskelen for å kunne delta på konferanser, kurs og faglige nettverk lavere. Studien peker på at både tilgang til kunnskap, rammevilkår og arbeidstid er viktige når leger vurderer å jobbe i allmennmedisin.

\section{LITTERATUR}

1. Birkeli CN, Rosta J, Aasland OG et al. Hvorfor velger leger seg bort fra allmennmedisin? Tidsskr Nor Legeforen 2020;140. doi: 10.4045/tidsskr.19.0597. [PubMed][CrossRef]

2. Rosta J, Bååthe F, Aasland OG et al. Changes in work stress among doctors in Norway from 2010 to 2019: a study based on repeated surveys. BMJ Open 2020; 10: e037474. [PubMed][CrossRef]

Publisert: 25. mai 2021. Tidsskr Nor Legeforen. DOI: 10.4045/tidsskr.21.0324

(C) Tidsskrift for Den norske legeforening 2023. Lastet ned fra tidsskriftet.no 26. april 2023. 